\title{
MONRATE: A descriptive tool for calculation and prediction of re-infection of Ascaris lumbricoides (Ascaridida: Ascarididae)
}

\author{
S.O. Sam-Wobo ${ }^{1}$, C.F. Mafiana ${ }^{1}$, S.A. Onashoga ${ }^{2}$ \& O.R.Vincent ${ }^{2}$ \\ 1 Department of Biological Sciences, University of Agriculture, PMB 2240, Abeokuta 110001, Ogun State, Nigeria. \\ Phone: 234-8033199315; sam_wobo@yahoo.com \\ 2 Department of Computer Sciences, University of Agriculture, PMB 2240, Abeokuta 110001, Ogun State, Nigeria.
}

Received 26-IV-2006. C Corrected 21-II-2007. Accepted 14-V-2007.

\begin{abstract}
The study presents an interactive descriptive tool (MONRATE) for calculating and predicting reinfection rates and time of Ascaris lumbricoides following mass chemotherapy. The implementation was based on the theoretical equation published by Hayashi in 1977, for time-prevalence: $\mathrm{Y}=\mathrm{G}\left[1-(1-\mathrm{X})^{\mathrm{N}-\mathrm{R}}\right]$ as modified by Jong-Yil in 1983. Using the Psuedo-Code of the MONRATE tool, the calculated monthly reinfection rates (X) for the LGAs are (names are locations in Nigeria in a region predominately populated by the Yoruba speaking tribes of Nigeria whose traditional occupations are agriculture and commerce): Ewekoro (1.6\%), Odeda (2.3 $\%$ ), Ado-odo/Otta (2.3\%), Ogun Waterside (3.8\%) and Obafemi/Owode (4.2\%). The mathematical mean of ' $\mathrm{X}$ ' values in the study areas for Ogun State was 2.84. The calculated reinfection time (N months) for the LGAs are varied such as Ado-odo/Otta (12.7), Ogun Waterside (21.8), Obafemi/Owode (22.92), Odeda (25.45), and Ewekoro (25.9). The mean value for $\mathrm{N}$ in Ogun State was 21.75. The results obtained from MONRATE were compared with those obtained using the mathematical equation and found to be the same. Rev. Biol. Trop. 55 (3-4): 755-760. Epub 2007 December, 28.
\end{abstract}

Key words: MONRATE, Ascaris lumbricoides, young worm positive rate, Ogun State.

In epidemiological aspects of ascariasis control, Jong-Yil (1983) had observed that the most important factor to be considered is the persistent occurrence of reinfection in endemic areas. It is known that, due to reinfection, the prevalence returned to the pre-treatment level within one year after intensive mass treatment using effective anti-helminths (Arfaa and Ghadirian 1977, Seo 1983). Therefore the success or failure in control greatly depends on the rate and frequency of reinfection.

Anderson (1986), and Forrester et al. (1990) had reported that helminth parasites were aggregated in human populations so that most individuals have very light infections while a few have great numbers of parasites, and that lightly infected individuals became lightly reinfected, whereas heavily infected individuals became heavily reinfected.

Seo (1983) had suggested that where prevalence and intensity of $A$. lumbricoides infection were high, the incidence (frequency) of reinfection would also be high. For instance, where the prevalence was $82-92 \%$, the monthly reinfection rate was $7.3-10.2 \%$, but where it was $36 \%$ the monthly rate was 3.3-4.8\%. This Jong-Yil (1983) stated may not totally be correct since the above study was based on repeated egg examination after treatment and not on the worm recovery. It further observed that if worm collection methods were applied with mass chemotherapy using anthelminths, the reinfection rate could be estimated simply by discriminating the cases harbouring young worm(s). The relationship between prevalence 
and reinfection rates in terms of all worms and young worm positive rates respectively could be applied to any given area. Therefore, the objectives of the present study was to develop a tool for calculating and predicting reinfection rates, by applying the formula of Hayashi (1977) and Jong-Yil (1983) through observation of epidemiological relationship between the current prevalence and the monthly reinfection rate of $A$. lumbricoides in communities of Ogun State, Nigeria.

\section{MATERIALS AND METHODS}

Ogun State lies approximately between $2^{\circ} 30^{\prime}$ $\mathrm{N}$ and $4^{\circ} 30^{\prime} \mathrm{NE}$ and between $6^{\circ} 30^{\prime} \mathrm{N}$ and $8^{\circ} \mathrm{N}$. It is predominately populated by the Yoruba speaking tribes of Nigeria whose traditional occupations are agriculture and commerce.

The Study areas were mapped using the soil-geological map of Ogun State (Sam-Wobo and Mafiana 2004). Consent and approval to use the primary school pupils were obtained from the State Primary Education Board after explaining the objectives of the study. Letters were thereafter issued to officials of the Local Government Education Authority in the study Local Government Areas, as well as to the Head Teachers in the selected primary schools for cooperation and assistance during the research study. In the four primary schools selected from each of the Local Government Areas, consent was also sought from the Parent/Teachers Association and the school children through interactive sessions facilitated by the Head teachers of each school.

Prevalence and Intensity by Direct Method: Levamex (containing $40 \mathrm{mg}$ of Levamisole and manufactured by UNIBIOS Laboratories Ltd, India) a broad-spectrum antihelminthic was administered to all participants in the study according to manufacturer's instructions. The pupils who took the drugs in our presence, were each given a labelled screw cap plastic container, about 1.51 with an instruction to pass all stools for the next $24 \mathrm{~h}$ into the container. Stool passed within $48 \mathrm{~h}$ of treatment was collected, preserved with $10 \%$ formalin and taken to the
Parasitology Laboratory in the Department of Biological Sciences, University of Agriculture, Abeokuta. Examination of Ascaris was by flushing the stool with running water through a sieve. The worms present were then sorted into sexes and counted. Before fixing the worms in $10 \%$ formalin, the length $(\mathrm{cm})$ and weight (gm) were obtained for characterization into young and adult worms. The length measurement was done by tracing a flexible wire through the anterior to posterior ends and the weight was measured using Mettler P163 weighing balance by Gallenkamp.

Statistical analysis: SPSS version 10 employing simple percentiles, paired and sample t-tests techniques were used in analysing the prevalence and intensity of infections, in addition to comparing infections and the frequency distribution probability factor $(\mathrm{k})$ of the worms in the study areas.

Reinfection studies: the method used for the prevalence and intensity studies was adopted. Each pupil previously treated was retreated 6 or 7 months after the initial treatment with Levamex. Thereafter, the pupils were requested to void all stools into the 1.51 container and bring to the school for two consecutive days. The stools were examined for young worms, which are indicative of fresh infection since the initial treatment.

Using the theoretical equation of Hayashi (1977) for time-prevalence:

$$
\begin{gathered}
\mathrm{Y}=\mathrm{G}\left[1-(1-\mathrm{X})^{\mathrm{N}-\mathrm{R}}\right] \\
\text { as applied by Jong-Yil (1983) }
\end{gathered}
$$

Where

$\mathrm{Y}=$ Prevalence

$\mathrm{X}=$ Monthly re-infection rate

$\mathrm{N}=$ Time elapsed in months

$\mathrm{R}=$ Incubation period for worm maturation

$\mathrm{G}=$ Maximum prevalence to be reached in the area.

The above equation was modified under the consideration that ' $G$ ' should be $1(100 \%)$ 
and ' $\mathrm{R}$ ' be 0 when ' $\mathrm{X}$ ' and ' $\mathrm{Y}$ ' values were expressed by worm positive rates as follows: $\mathrm{Y}=1-(1-\mathrm{X})^{\mathrm{N}}$

The monthly re-infection rate therefore was obtained using the known values of ' $\mathrm{Yr}$ ' (Young worm positive rate) and ' $\mathrm{N}$ ' (no in months) according to the equation

$$
\mathrm{Yr}=1(1-\mathrm{X})^{2}
$$

A tool named "MONRATE" using either the FORTRAN or Q-Basic programming languages was implemented for the calculation and prediction of reinfection rate $(\mathrm{N})$ as a quality assurance tool for the Jong-Yil (1983) model.

\section{Psuedo-Code to calculate and predict re- infection time:}

Clear the screen

Array r (20)

Array y (20)

Do $i$ from 1 to 20: A loop I to read each of the values in $r$

Read $r$ (i): read in each value of $r$

LET $x=1-S Q R(1-(r(i) / 100))$ - to get the monthly re-infection rate

output the result of $\mathrm{x}$

get the next value of $r$

Do $\mathrm{J}$ from 1 to 20: A loop $\mathrm{j}$ to read the values of $y$

Read Y(J): read in each value of $y$

LET $n=\operatorname{LOG}(1-(\mathrm{Y}(\mathrm{j}) / 100)) / \operatorname{LOG}(1-\mathrm{x}) \quad$ - this calculates the time elapsed in months output the each value of $n$ read in the next value of $y$

end program execution

Note:

r: represents the worm positive case values $\mathrm{y}$ : represents the young worm positive case values

\section{RESULTS}

Direct prevalence and intensity of infection: one thousand six hundred pupils (51\% males: $49 \%$ females) within the age classes 6-17 years were examined for direct prevalence in the different Local Government Areas (LGAs). The level of compliance of the pupils with respect to faecal collection after treatment in the study revealed that Odeda LG School, Obantoko had the least compliance (19\%), while the highest was in Anglican School, Obafemi (96.3\%). On the whole, there was 62 $\%$ compliance.

The study observed that 480 pupils of the 990 pupils who complied with faecal collection passed out worms (Table 1). The result showed that $51.9 \%$ male and $48.1 \%$ female pupils were infected with $A$. lumbricoides. Statistical analysis showed no significant difference between the infection rates in both sexes $(\mathrm{t}=2.60, \mathrm{p}=0.234)$. The study also observed that male pupils voided higher numbers of worms $(1090,0=2.2)$ than female pupils $(879$, $0=1.7$ ) in all the study areas. The overall direct prevalence for $A$. lumbricoides was $48.5 \%$ for the population that complied with faecal collection; and $30 \%$ for the total population enlisted for the study.

Reinfection analysis: from the 1237 pupils who participated in the study, a total of 102 young worms were voided by 70 young worm positive cases with a mean worm burden of 1.4 worms. The young worm positive rates in the study areas were in the range of 3.2 to 8.2 $\%$. Of the initial 480 worm positive cases, 70 cases were positive for young worms (Table 1). Using the Psuedo-Code of the MONRATE tool, the calculated monthly reinfection rates $(\mathrm{X})$ for the LGAs are: Ewekoro (1.6\%), Odeda (2.3\%), Ado-odo/Otta (2.3\%), Ogun Waterside (3.8\%) and Obafemi/Owode (4.2\%). The mathematical mean of ' $\mathrm{X}$ ' values in the study areas for Ogun State was 2.84. The calculated reinfection time (N months) for the LGAs are varied such as Ado-odo/Otta (12.7), Ogun Waterside (21.8), Obafemi/Owode (22.92), Odeda (25.45), and Ewekoro (25.9). The mean value for $\mathrm{N}$ in Ogun State was 21.75. 


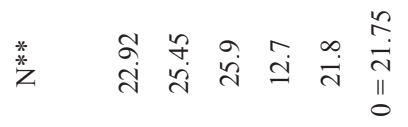

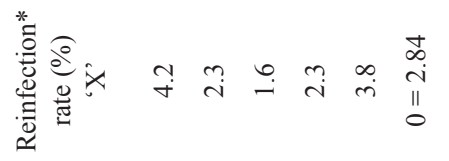

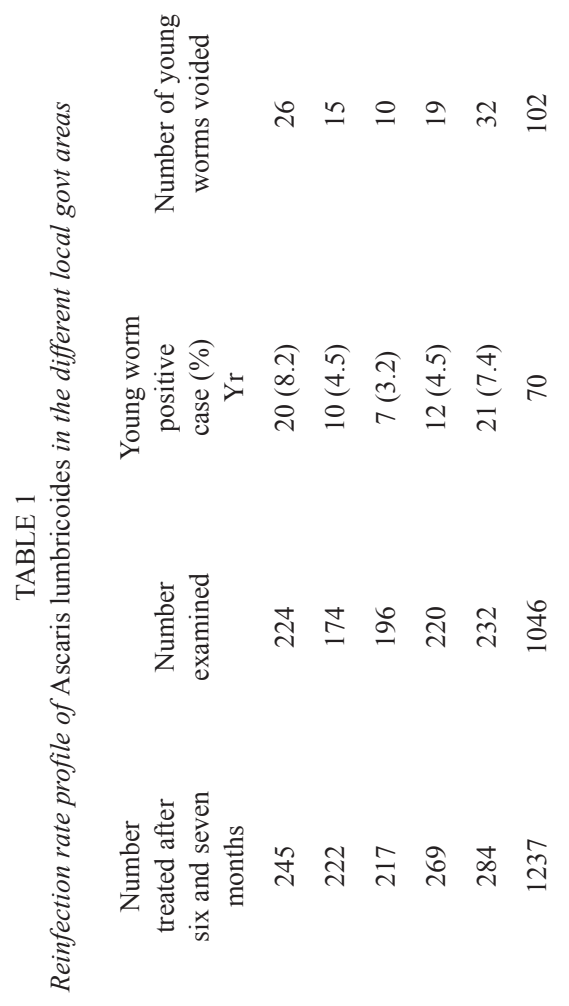

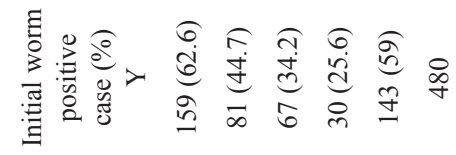

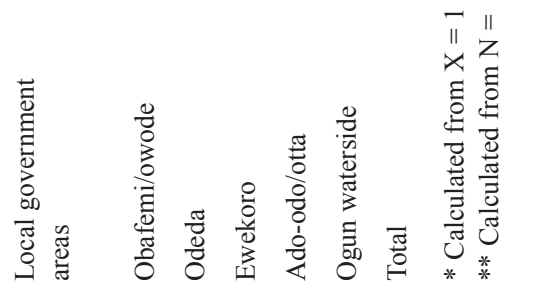

\section{DISCUSSION}

The study showed that the overall prevalence by direct intensity of $A$. lumbricoides in Ogun State through the School system was $48.5 \%$. The study developed a descriptive tool "MONRATE" for determination of monthly reinfection rate and reinfection time in months. This algorithm which is novel was test run and used in the determination of the values obtained for the reinfection. The values obtained were the same as the reinfection formula of Jong-Yil (1983) which served as the control.

The mean monthly reinfection rate calculated was 2.84 which are approximately three months for schools in Ogun State. In assessing reinfection time for the State, an ' $\mathrm{N}$ months' mean value of 21.75 was obtained. The study adopted the use of mathematical means to develop an algorithm without altering the original contributions of Jong-Yil in the reinfection formula.

The significance of the new tool is realised with the development of information technology where computers are incorporated in our daily activities. It now becomes easier for programme control officers and epidemiologists to adapt the tool in calculating and predicting reinfection time. This also eliminates the stress basic biomedical practitioners go through in solving mathematical equations.

The result of this study is therefore a veritable instrument in the execution of control programmes involving mass treatment and health education at the private and community levels. Three months periodic treatment with anthelminths would not only cut off re-infection time due to ascariasis but would also improve the morbidity status of the affected individual.

Anderson (1993) had opined that the important characteristic of highest responses to helminth infection is the density-dependent manner in which they act. The proportional reduction in establishment, survival and reproduction is greater in disease subpopulation of parasites than sparse ones. These processes act as negative feedback mechanism to constrain parasite population growth within individual 
lust. Although immunological responses induce such effects, competition between parasites for finites resources within or on the host, may also be important.

Studies had posited that gastro-intestinal helminths are amenable to control in that they require no intermediate host, however the extent and prevalence of gastro-intestinal infections globally had continued to pose a marine problem in recent decades (Molyneux 1993). An integrated approach consisting of mass treatment, safe disposal of waste and provision of latrines in addition to the need for community and health education had been canvassed.

The absolute determination of worm burden by chemotherapy induced expulsion of helminth particularly Ascaris by one dosage treatment with levamisole is indicative that chemotherapy is the best option for treatment (Haswell-Elkins et al. 1989, Holland et al. 1989, Guyatt et al. 1995). Urbani and Albonico (2003) while confirming four anthelminthic drugs namely: Albendazole, Levamisole, Mebendazole and Pyrantel as appropriate single dose treatment against soil-transmitted helminthiasis, sounded a note of caution on reported side effects and severe adverse reactions associated with the drugs. They however advocated further research to confirm the cause-effect relationship.

\section{ACKNOWLEDGMENTS}

We sincerely appreciate the support and cooperation of Ogun State Primary Education Board, the Head Teachers, Parents, Staff and Pupils of the schools participating in the study.

\section{RESUMEN}

Se presenta una herramienta descriptiva e interactiva (MONRATE) para calcular y predecir las tasas y tiempo de reinfección con Ascaris lumbricoides tras un tratamiento de quimioterapia. Nos basamos en la ecuación propuesta por Hayashi en 1977 para el tiempo de prevalencia: $Y=G$ [1-
$(1-\mathrm{X})^{\mathrm{N}-\mathrm{R}}$ ], según la modificó Jong-Yil en 1983. Utilizando el código Psuedo de la herramienta de MONRATE, las tasas de reinfección mensuales (X) para varios sitios de Nigeria, África, son: Ewekoro (1.6\%), Odeda (2.3\%), Ado-odo/Otta (2.3\%), Ogun Waterside (3.8\%) y Obafemi/ Owode (4.2\%). El promedio matemático de los valores de "X" en el área de estudio del Estado de Ogun fue 2.84. El tiempo de reinfección calculado ( $\mathrm{N}$ meses) para LGAs es variado: Ado-odo/Otta (12.7), Ogun Waterside (21.8), Obafemi/Owode (22.92), Odeda (25.45) y Ewekoro (25.9). El valor promedio para $\mathrm{N}$ en el Estado de Ogun fue 21.75. Los resultados del programa MONRATE son iguales a los producidos por la ecuación

Palabras clave: MONRATE, Ascaris lumbricoides, tasa de casos positivos para presencia de vermes jóvenes, Estado de Ogun.

\section{REFERENCES}

Anderson, R.M. 1986. The population dynamics and epidemiology of intestinal nematode infections. Transact. Royal Soc. of Trop. Med. Hyg. 80: 686-696.

Anderson, R.M. 1993. Epidemiology, p. 75-116. In F.E.G. Cox (eds.). Modern Parasitology, Blackwell, Oxford, England.

Arfaa, F. \& E. Ghadirian. 1977. Epidemiology and masstreatment of Ascariasis in six rural communities in central Iran. Am. J. Trop. Med. Hyg. 26: 866-871.

Forrester, J.E., M.E Scott, D.A.P. Bundy \& M.H.N. Golden. 1990. Predisposition of individuals and families in Mexico to heavy infection with $A$. lumbricoides and T. trichiura. Transact. Royal Soc. of Trop. Med. Hyg. 84: 272-276.

Guyatt, H.L., M.S. Chan., G.F. Medley \& D.A.P. Bundy. 1995. Ascaris Infection by chemotherapy: which is the most cost-effective option?. Transact. Royal Soc. Trop. Med. Hyg. 89: 16-20.

Haswell-Elkins, M.R., D. Elkins \& R.M. Anderson. 1989. The influence of individual, social group and household factors on the distribution of Ascaris lumbricoides within a community and implication for control strategies. Parasitology 98: 125-134.

Hayashi, S. 1977. A model for the evaluation and assessment of the effect of control of the soil-transmitted helminthiases. Proceedings of the $4^{\text {th }}$ APCO Conference, Tokyo: 297-311 
Holland, C.V., S.O. Asaolu, D.W.T. Crompton., R.C. Stoddart., R .Macdonald \& S.E.A. Torimiro. 1989. The epidemiology of $A$. lumbricoides and their soil transmitted helminths in primary school children from Ile-Ife, Nigeria. Parasitology 99: 275-285.

Jong-Yil, C. 1983. Epidemiological studies on Ascaris lumbricoides re-infection in rural communities in Korea. The relationship between prevalence and monthly reinfection rate. Korean J. Parasit. 21: 135-141.

Molyneux, D.H. 1993. Control, p 243-261. In F.E.G. Cox (eds.). Modern Parasitology Blackwell, Oxford, England.
Sam-Wobo, S.O. \& C.F. Mafiana. 2004. The effects of surface soil exchangeable cations on the prevalence of Ascaris lumbricoides in Ogun State, Nigeria. Nigerian J. Parasit. 25: 25-31.

Seo, B.S. 1983. Control problems of ascariasis in Korea with special reference on the related biology and epidemiology. Collected Papers on the Control of soil-transmitted Helminthiasis 2: 194-216.

Urbani, C. \& M. Albonico. 2003. Anthelminthic drug safety and drug administration in the control of soiltransmitted helminthiasis in community campaigns. Acta Tropica: 215-221. 